\title{
The Influence of Entrepreneurial Orientation and Innovation Capability on Perceived Firm Performance with the Mediating Role of Market Orientation Case study in PT WIKA Industri \& Konstruksi
}

\author{
Anggiat Maju Lubis ${ }^{1 *}$, Firdaus Basbeth ${ }^{2}$ \\ ${ }^{12}$ Sekolah Tinggi Manajemen IPMI, DKI Jakarta 12750, Indonesia
}

\begin{tabular}{|c|c|}
\hline A B S T R A C T & ARTICLE INFO \\
\hline $\begin{array}{l}\text { Performance of PT WIKON in two consecutive years indicated run } \\
\text { into downtrend from the year } 2018 \text { to the year 2019. Low levels of } \\
\text { Entrepreneurial Orientation, Innovation Capability, and Market } \\
\text { Orientation have been suspected as factors leading to the } \\
\text { performance of PT WIKA Industri \& Konstruksi. The objective of } \\
\text { this study is to investigate Market Orientation as the mediator of } \\
\text { relationship Entrepreneurial Orientation and Innovation Capability } \\
\text { on Firm Performance in a construction company. However, study- } \\
\text { related Market Orientation as a mediator on the indirect effect of } \\
\text { Innovation Capability and Firm Performance is still rare, therefore } \\
\text { research on this subject can be seen as Novelty. There are Six } \\
\text { theory-based hypotheses are measured. This research employs a } \\
\text { quantitative approach with empirical evidence of employees and } \\
\text { BOD of PT WIKA Industri \& Konstruksi. Survey data are from } 93 \\
\text { respondents were analyzed used structural equation modeling } \\
\text { (SEM). The findings of this research showed that Market } \\
\text { Orientation has a positive effect on Firm Performance. Surprisingly, } \\
\text { Entrepreneurial Orientation (EO) and Innovation Capability (IC) } \\
\text { independently do not have a direct effect on Firm Performance. } \\
\text { The Effect of Entrepreneurial Orientation (EO) on Firm Performance } \\
\text { (FP) is mediated by Market Orientation. Likewise, the effect of } \\
\text { Innovation Capability (IC) on Firm Performance (FP) is mediated by } \\
\text { Market Orientation. These results suggest that Entrepreneurial } \\
\text { Orientation and Innovation Capability should focus on Market } \\
\text { Orientation to improve the overall Firm Performance. Besides, it } \\
\text { is highly recommended to middle management and above of PT } \\
\text { WIKA Industri \& Konstruksi should focus and allocate resources } \\
\text { to Market Orientation to improve their Firm Performance. }\end{array}$ & $\begin{array}{l}\text { Article History: } \\
\text { Received : 16-11-2020 } \\
\text { Revised : :9-06-2021 } \\
\text { Accepted : 24-09-2021 } \\
\text { Published : 31-10-2021 } \\
\text { Keywords: } \\
\text { Entrepreneurial Orientation } \\
\text { Innovation Capability } \\
\text { Market Orientation } \\
\text { Firm Performance } \\
\text { SEM-PLS } \\
\text { State-Owned Construction- Company } \\
\text { JEL: M12, M31, M21 }\end{array}$ \\
\hline
\end{tabular}


Copyright (C) 2020 Authors. This is an open access article distributed under the Creative Commons Attribution License, which permits unrestricted use, distribution, and reproduction in any medium, provided the original work is properly cited.

\section{INTRODUCTION}

According to data from the central statistics agency (BPS Statistics), since 2014, the Indonesia Construction sector has been contributed to around $9-10 \%$ of Indonesia's GDP. The capitalization value of the construction sector continues to increase year on year. Indonesia has become the second-largest construction market in Asia after China (Dirjen Bina Konstruksi Kemenpupera, 2015). Indonesia's government has been increasing the infrastructure budget since 2015 from 256 Trillion Rupiah to 420 trillion Rupiah in 2019. This makes the construction sector has become the third-largest contributor to the Indonesian economy. The construction sector is placed only behind the Industry and trading sectors, which represent $19.8 \%$ of GDP and $13 \%$ of GDP. Indonesia also has a large number of constructions establishment company by business scale. The number of the registered construction company in Indonesia establishment by the business scale in 2018 were 160.576 companies, whereby 130.771 small, 28.254 medium and 1551 large company (BPS statistic Indonesia 2018).

The construction sector is a highly competitive industry, high-risk business, and requires a large capital value and high safety standard. However, construction firms are asked to perform well. The performance of the construction company needs to be measured on an annual basis for business planning needs. Companies should be asked to evaluate the factors that influence their performance. Businesses with good performance are businesses that excel in metrics such as profitability, product \& process, customer satisfaction, employee engagement, and leadership.

PT WIKA Industri \& Konstruksi (PT. WIKON) is one of the subsidiary companies of PT Wijaya Karya (WIKA) which focuses on EPI of steel and automotive also face the same difficulties as any other construction firm. In two (2) consecutive years, PT WIKON has never been achieved the performance target and run into a downtrend from the year 2018 to the year 2019. The performance indicators of PT WIKA Industri \& Konstruksi (WIKON) showed poor innovation, low index of customer satisfaction, drop in sales \& growth, and low productivity. The low level of Entrepreneurial Orientation (EO), Market Orientation (MO), and Innovation Capability (IC) in the organization has been suspected as a factor leading to the poor performance of PT WIKON. Therefore, this thesis focused on researching the influence of Entrepreneurial Orientation and Innovation Capability on Firm Performance with the mediating role of Market Orientation (MO) empirical evidence in PT WIKA Industri \& Konstruksi (PT. WIKON).

Based on the problem statement proposed in this study, the objectives of this study are: (1) To evaluate and analyze the effect of Entrepreneurial Orientation (EO) on Market Orientation (MO), (2) To evaluate and analyze the effect of Innovation Capability (IC) on Market Orientation (MO), (3) To evaluate and analyze the effect of Market Orientation (MO) on Firm Performance (FP),(4) To evaluate and analyze the effect of Entrepreneurial Orientation (EO) on Firm Performance (FP), (5) To evaluate and analyze the effect of Innovation Capability (IC) on Firm Performance (FP), and (6) To determine the role of Market Orientation, mediate the effect of Entrepreneurial Orientation \& Innovation Capability on Firm Performance in PT WIKA Industri \& Konstruksi.

\section{LITERATURE REVIEW}

\section{Entrepreneurial Orientation and Market Orientation}

Entrepreneurial Orientation (EO) represents the level to which the company's growth goals are driven by the discovery and development 
Of untapped business opportunities. Market Orientation represents the level to which the strategic business planning of the company is driven by consumer and competitor intelligence. Matsuno et al. (2002) found that market Orientation is driven by entrepreneurial orientation. The higher the level of entrepreneurial orientation, the higher the level of Market orientation. Baker and Sinkula (2009) also report that there is a significant relationship between Entrepreneurial Orientation (EO) and Market Orientation (MO). Based on the previous result study, this study examines the positive influence of Entrepreneurial Orientation (EO) on Market Orientation in PT WIKA Industri \& Konstruksi, hence:

H1: Entrepreneurial Orientation has a positive effect on Market orientation.

\section{Innovation Capability and Market Orientation}

Several researchers have found a positive relationship between Innovation Capability and Market Orientation conducted by Kahn (2001), Han et al (1998), and Christiansen (2000). According to Frambach and Schillewearth (2002), the Innovation of a new product and service would not be effective when the company does not recognize the needs of consumers and competing products properly. Market orientation compares the capabilities of the company itself with the capabilities of its competitors, therefore companies are forced to build their capacity for innovation. The innovation capability can be used to recognize strategic opportunities that help the company create new goods and services for the market, as well as to stimulate leadership roles (Bozick, 2006). Based on the above explanation, this study examines the positive influence of Innovation Capability on Market Orientation in PT WIKA Industri \& Konstruksi, hence:

H2: Innovation Capability has a positive effect on Market orientation.

\section{Market Orientation and Firm Performance}

Narver and Slater (1990) define the Market Orientation concept as an organizational culture that cultivates the required behaviors for superior customer value and then leads to higher
Company performance. A Company that uses Market Orientation can attain a competitive advantage and higher business performance (Gruber-Muecke and Hofer, 2015). MO enables the Companies to understand the market, and according to the customer needs and wants, they develop the strategy about the product and services (Liu et al, 2002). Based on the explanation above, this study examines the positive influence of Market Orientation on Company performance in PT WIKA Industri \& Konstruksi, hence:

H3: Market orientation has a positive effect on Company performance.

\section{Entrepreneurial Orientation and Firm Performance}

Several different studies have shown that the performance of the organizations which implements the entrepreneurial orientation more is better than those who do not adopt the EO (Kajalo \& Lindblom, 2015; Lumpkin \& Dess, 1996; Rauch, et al., 2009; Covin \& Slevin, 1986; Hult, Snow, \& Kandemir, 2003; Lee, Lee \& Pennings, 2001; Wiklund \& Shepherd 2003), while several studies show that there is low co-relation of EO with the performance (i.e., Dimitratos, Lioukas, \& Carter, 2004; Lumpkin \& Dess, 2001) and research also unable to show any significant co-relation between EO and performance (George, Wood, \& Khan, 2001; Covin, Slevin, \& Schultz, 1994). Regardless of the contradictories result above, this study examines the positive impact of Entrepreneurial Orientation on Company performance in PT WIKA Industri \& Konstruksi, hence:

H4: Entrepreneurial orientation has a positive effect on Firm Performance.

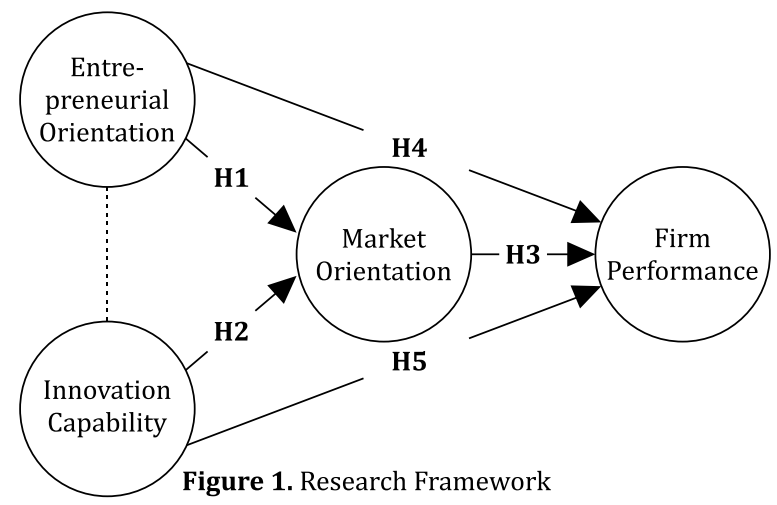




\section{Innovation Capability and Firm Performance}

Many researchers like Jimenez and Sanz-Valle (2011), Allred and Swan (2005), Wang and Wang (2012), and Alam (2013) found innovation capability has a positive effect on performance. Companies with innovation capability tend to support new ideas and novelty, and further increase the engagement in developing new products or processes (Lumpkin and Dess, 1996; Li et al., 2009). Innovation Capability in this study was operationalized according to Calik et al (2017) through the following indicators i.e. Product, Process, Organization, Culture, and Marketing Innovation Capability. Based on the explanation above, this study examines the relationship of Innovation Capability and Company performance in PT WIKA Industri \& Konstruksi, hence:

H5: Innovation Capability has a positive effect on Company performance.

\section{Market Orientation, Entrepreneurial Orientation, Innovation Capability, and Firm Performance}

Ruzgar NS (2014) found that Market Orientation enhances the relationship between Entrepreneurial Orientation (EO) and Performance. Similar to the above study, Amin et al (2016) and Baker \& Sinkula (2009) also found that the Mediating effect of MO significant influence on the relationship between Entrepreneurial Orientation and Performance. Other research also show mediating role of market orientation in the link between entrepreneurial intention (EO) and performance (Vega-Vázquez, Cossío-Silva et al. 2016) (I have added 1 more of previous researchs). While study related to the indirect relationship between Innovation Capability and Performance with the mediating role of Market Orientation is still scarce. However, a few kinds of research have empirically analyzed Market Orientation mediate the relationship both Entrepreneurial Orientation \& Innovation Capability with Company performance. Hence, the author hypothesizes: H6: Market Orientation mediates Indirect effect of Entrepreneurial Orientation \& Innovation Capability on Firm Performance.

\section{RESEARCH METHOD}

This study uses the research onion approach. The philosophy of research is positivism, where data collection is taken from a representative sample in PT WIKON with a deductive approach. This research uses the Quantitative research method to examine the effect of chosen variables and to analyze the causal effects caused by these variables logically. The researcher obtained data from the questionnaire adopted from the previous study. The population of this research was taken based on a predetermined population represented by the Supervisor and a similar level, Manager and senior management level, and BOD level. The survey questionnaire is constructed using the google form. The questionnaire was delivered to 147 respondents by an online survey in September 2020 to the employees and BOD of PT WIKON. This research uses a probability sampling technique with proportionate stratified random sampling. The proportion of BOD level, Senior, and Manager, and Supervisor is 1:10:20.

This research used four (4) operational constructs that have been used from a previous study wherein Entrepreneurial Orientation (EO) and Innovation Capability (IC) are as Independent Variable, Market Orientation is as Mediating Variables and Firm Performance (FP) is as Dependent Variable. Entrepreneurial Orientation was measured using five (5) indicators from Lumpkin \& Dess (2005), and Solikahan EZ \& Mohammad (2019) namely (1) Innovativeness (2) Proactive (3) Risk-Taking (4) Aggressive and (5) autonomy. Innovation Capability was measured using Calik et al (2017) measurement. Market Orientation was measured using Narver \& Slater (1990) and Kiessling et al (2016) measurement. While Firm Performance was adapted from Franco Santos et al (2007). All the measurements using 5 points Likert scale with anchor points $1=$ strongly disagree and 5 = strongly agree. To test the theoretical model, SEM-PLS (Structural Equation Model Partial Least Square was applied for constructing predictive models. 


\section{RESULT \& DISCUSSION}

Based on SEM-PLS analysis, the most important driver for Firm Performance (FP) is Market Orientation (MO) with path coefficient 0.653 however the path coefficient of EO and IC are incredibly low or close to 0 . While the important driver for Marketing Orientation (MO) is IC (0.518) and EO (0.428). Whether a path coefficient is significant, it can be examined by calculating the empirical t-values and p-values for all structural path coefficient. The coefficient statistically significant if the t-value is larger than 1.96 (significance level = 5\%) for a twotailed test and the p-value must be smaller than 0.05 . Assuming a $5 \%$ significance level, we find that relationship in the structural model $\mathrm{EO} \rightarrow$ MO ( $p=0.000), \quad I C \rightarrow$ MO $(p=0.0000)$ and $M O \rightarrow C P$ $(\mathrm{p}=0.000)$ are significant, however relationship between $\mathrm{EO} \rightarrow \mathrm{CP}(\mathrm{p}=0.434)$ and $\mathrm{IC} \rightarrow \mathrm{CP}(\mathrm{p}=0.475)$ is not significant.By calculating the bootstrapping procedure in Smart PLS to the structural model, this study found that:

The hypothesis $\mathrm{H} 1$ with $\mathrm{t}$ value $=3.894$ and p-value $=0.000$. thus, it justifies hypothesis $\mathrm{H} 1$ is accepted wherein higher implementation of Entrepreneurial Orientation positively and significantly raise the implementation of Market Orientation in PT Wika Industri \& Konstruksi. This finding is in line and consistent with the previous study conducted by Matsuno et al (2002), Hassim et al (2011), and Amin, M et al, 2016) which suggested Entrepreneurial Orientation behavior is positively and significantly influencing market orientation.

The hypothesis $\mathrm{H} 2$ with the $\mathrm{t}$ value $=4.690$ and p-value $=0.000$, thus, it justifies the hypothesis $\mathrm{H} 2$ is accepted wherein higher Innovation Capability positively and significantly raise the implementation of Market Orientation in PT Wika Industri \& Konstruksi. This research finding is consistent with the previous studies conducted by Kahn (2001), Han et al (1998), and Christiansen (2000) which found a positive relationship between Innovation Capability and Market Orientation.
The hypothesis $\mathrm{H} 3$ with the $\mathrm{t}$ value $=4.770$ and p-value $=0.000$, thus, it justifies the Hypothesis H3 has accepted wherein higher Implementation of Market Orientation positively and significantly raise the Firm Performance. This research finding is consistent with the previous studies suggested by Cano et al.,2004), Amin et al (2016) and Slater and Narver (2000), Pulendran et al (2000), and Tray \& Morgan (2002) that Market Orientation and Performance are positively and significantly related.

The hypothesis $\mathrm{H} 4$ with the $\mathrm{t}$ value $=0.782$ and $\mathrm{p}$-value $=0.434$. Thus, hypothesis $\mathrm{H} 4$ is rejected which means this research found the implementation of Entrepreneurial Orientation has a low and insignificant direct effect on Company Performance in PT WIKA Industri \& Konstruksi. This research result is contrary to several studies that the adoption of the Entrepreneurial Orientation could improve performance which is indicated by Kajalo \& Lindblom (2015), G Tom Lumpkin \& Dess (1996), Rauch, et al (2009), and Li et al (2009). However, there are some studies which in line with the result find that there is a low and insignificant relationship between Entrepreneurial Orientation and Performance (Dimitratos et al, 2004; Lumpkin \& Dess, 2001, George et al, 2001; Covin et al, 1994). According to Rauch et al (2011), the magnitude of the relationship between Entrepreneurial Orientation and Performance varies across studies depends on the characteristic of the environment and the company itself.

What is the meaning of red colour in the table? Can describes? The values do not meet the requirement $t$-value $<1.96$ and $p$-values $>0.05$. but I already made it same colour with others.

The hypothesis $\mathrm{H} 5$ with the $\mathrm{t}$ value $=0.715$ and $\mathrm{p}$-value $=0.475$. Thus, hypothesis $\mathrm{H} 5$ is rejected which means this research found Innovation Capability has a low and insignificant direct effect on Firm Performance in PT WIKA Industri $\&$ Konstruksi. This research result is contrary to previous research conducted by Jimenez and 
Table 1. Result of Hypothesis Testing

\begin{tabular}{|c|c|c|c|c|}
\hline Relationship & Path Coefficient & t- values & P-values & Result \\
\hline Entrepreneurial Orientation $\rightarrow$ Market Orientation & 0.428 & 3.894 & 0.0000 & H1 supported \\
\hline Innovation Capability $\rightarrow$ Market Orientation & 0.518 & 4.690 & 0.0000 & H2 supported \\
\hline Market Orientation $\rightarrow$ Company Performance & 0.653 & 4.770 & 0.0000 & H3 Supported \\
\hline Entrepreneurial Orientation $\rightarrow$ Company Performance & 0.134 & 0.782 & 0.434 & H4 not supported \\
\hline Innovation Capability $\rightarrow$ Company Performance & 0.107 & 0.715 & 0.475 & H5 not supported \\
\hline $\begin{array}{l}\text { Market Orientation mediate the relationship of EO on Firm } \\
\text { Performance }\end{array}$ & 0.413 & 3.157 & 0.002 & \multirow{2}{*}{ H6 supported } \\
\hline $\begin{array}{l}\text { Market Orientation mediate the relationship of IC on Firm } \\
\text { Performance }\end{array}$ & 0.446 & 3.270 & 0.001 & \\
\hline
\end{tabular}

Note: significant level of 5\% (2-tailed)

Sanz-Valle (2011), Allred and Swan (2005), and Wang and Wang (2012) which found Innovation Capability influences performance significantly.

The hypothesis $\mathrm{H} 6$ with the $\mathrm{t}$-value $=3.157$; $\mathrm{p}$-value $=0.002$ and $\mathrm{t}$-value $=3.270 ; \mathrm{p}$-value $=0.001$. Thus, it justifies hypothesis $\mathrm{H} 6$ is accepted wherein Market Orientation positively and significantly support the indirect effect of Entrepreneurial orientation and Innovation Capability on Firm Performance in PT Wika Industri \& Konstruksi. This study finds that both Entrepreneurial Orientation and Innovation Capability influence Firm Performance indirectly through the mediating role of Market Orientation. This finding is consistent with a study conducted by Ruzgar, NS et al (2014) which found that the Market Orientation (MO) enhances the relationship between Entrepreneurial Orientation and Performance. While the research of Indirect Relationship between Innovation Capability and Firm Performance with the presence of the Mediating variable of Market Orientation is still rare. Therefore, research on this subject can be seen as a Novelty.

\section{CONCLUSION}

There was a significant positive effect of Entrepreneurial Orientation (EO) and Innovation Capability (IC) on Market Orientation (MO). This shows the higher level of Entrepreneurial Orientation and Innovation Capability the higher implementation of market orientation in PT WIKA Industri \& Konstruksi.
There was a significant positive effect of Market Orientation (MO) on Firm Performance (FP). This shows that higher implementation of Market Orientation the higher Firm Performance can be achieved in PT WIKA Industri \& Konstruksi. While Entrepreneurial Orientation (EO) and Innovation Capability (IC) has a low and insignificant effect on Firm Performance (FP). This means that the higher level of Entrepreneurial Orientation and Innovation Capability does not influence directly Firm Performance in PT WIKA Industri \& Konstruksi.

Market Orientation mediates the indirect effect of Entrepreneurial Orientation and Innovation Capability on Firm Performance. This shows that Market Orientation has a significant role as a mediator on the indirect effect of Entrepreneurial Orientation on Firm Performance. This also shows that Market Orientation has a significant role as a mediator on the indirect effect on Innovation Capability on Firm Performance. This result means that higher implementation of EO and IC followed by Implementation of Market Orientation can raise Firm Performance achievement of PT WIKA Industri \& Konstruksi.

\section{RECOMMENDATION}

The future researcher can use the same construct to be tested in several construction companies instead of one company to generate highquality research. It is also highly recommended to conduct a similar test with a large number of samples to get a better answer from respondents. In this study, the author use Market Orientation 
as a mediating variable on the indirect effect to influence the Firm Performance, however, the future researcher can use Market Orientation (MO) as a moderating variable on the relationship of Entrepreneurial Orientation (EO), Innovation Capability (IC) on Firm Performance.

To improve PT WIKON Firm Performance, it is recommended to be more implement a market orientation in PT WIKON's business. PT WIKON should be more focused on the customer by creating greater value and having a commitment to serve the customer. More focus to the competitor by providing a competitive advantage to customer., and coordination of inter-functional more intense for serving the customer needs.
Then to improve the level of Market Orientation in PT WIKON, it is also recommended to PT WIKON to be more implement Entrepreneurial Orientation as a culture within the company. PT WIKON must encourage the employees especially in middle management and above to be more innovative in their work process, proactively identifies future needs of customer and risktaking in exploiting opportunities. PT WIKON must also provide autonomy to its employees to do their jobs. Besides, PT WIKON must increase its Innovation Capability as well. PT WIKON. PT WIKON must improve innovation capabilities in product / service, process, organization, marketing, and cultural innovation.

\section{REFERE N C E S}

Al Mamun, A., \& Fazal, S. A. (2018). Effect of entrepreneurial orientation on competency and microenterprise performance. Asia Pacific Journal of Innovation and Entrepreneurship.

Asad, M., Sharif, M., \& Hafeez, M. (2016). The moderating effect of network ties on the relationship between entrepreneurial orientation, market orientation, and performance of MSEs. Paradigms A Research Journal of Commerce, Economics, and Social Sciences, 10(2), 74-81.

Brouthers, K. D., Nakos, G., \& Dimitratos, P. (2015). SME entrepreneurial orientation, international performance, and the moderating role of strategic alliances. Entrepreneurship theory and practice, 39(5), 1161-1187.

Engelen, A., Gupta, V., Strenger, L., \& Brettel, M. (2015). Entrepreneurial orientation, Company performance, and the moderating role of transformational leadership behaviors. Journal of Management, 41(4), 1069-1097.

Hafeez, S., Siddiqui, Z. U., \& Rehman, K. U. (2011). The effect of market and entrepreneurial orientation on Company performance. Information Management and Business Review, 3(6), 389-395.

Hassim, A. A., Asmat-Nizam, A.-T., \& Bakar, A. R. A. (2011). The effects of entrepreneurial orientation on Company organisational innovation and market orientation towards Company business performance. International on Sociality ND Economics Development. IPEDR, 10, 280-284.

Hussain, J., Abbas, Q., \& Asad Khan, M. (2018). Entrepreneurial Orientation and Performance: The Moderating Effect of Market Orientation. 7, 2017.

Lumpkin, G. T., \& Dess, G. G. (2015). Entrepreneurial orientation. Wiley Encyclopedia of Management, 1-4.

Migliori, S., Pittino, D., Consorti, A., \& Lucianetti, L. (2019). The relationship between Entrepreneurial Orientation, Market Orientation and Performance in University Spin-Offs. International Entrepreneurship and Management Journal, 15(3), 793-814. doi:10.1007/s11365-017-0488-x

Rajapathirana, R. J., \& Hui, Y. (2018). Relationship between innovation capability, innovation type, and Company performance. Journal of Innovation \& Knowledge, 3(1), 44-55.

Stam, W., \& Elfring, T. (2008). Entrepreneurial orientation and new venture performance: The moderating role of intra-and extraindustry social capital. Academy of management journal, 51(1), 97-111. 
Subagja, I., Astuti, W., \& Darsono, J. (2019). The influence of market orientation, learning orientation, and entrepreneurial orientation toward innovation and impact on company performance.

Veidal, A., \& Korneliussen, T. (2013). Entrepreneurial orientation and market orientation as antecedents of organisational innovation and performance. Int. J. of Entrepreneurship and Small Business, 19, 234-250. doi:10.1504/IJESB.2013.054965 